\title{
Microstructure Properties of Rapidly Solidified Al-Zn-Mg-Cu Alloys
}

\author{
Emad M. Ahmed ${ }^{1,2}$ \\ ${ }^{1}$ Solid State Physics Department, National Research Center, Dokki, Giza 12311, Egypt \\ ${ }^{2}$ Physics Department, Faculty of Science, Taif University, P.O. Box 888, Taif 21974, Saudi Arabia
}

Correspondence should be addressed to Emad M. Ahmed; makboul67@yahoo.com

Received 12 December 2013; Accepted 18 January 2014; Published 2 March 2014

Academic Editors: U. De, A. K. Meikap, and K. Sahoo

Copyright (C) 2014 Emad M. Ahmed. This is an open access article distributed under the Creative Commons Attribution License, which permits unrestricted use, distribution, and reproduction in any medium, provided the original work is properly cited.

\begin{abstract}
The Rietveld X-ray diffraction analysis was applied to analyze the weight fraction of precipitation phases and microstructure characterizations of rapidly solidified Al- $8 \mathrm{Zn}-4 \mathrm{Mg}-x \mathrm{Cu}, x=1,4,8$, and 10 alloys (in wt.\%), prepared by melt spun technique. A good agreement between observed and calculated diffraction pattern was obtained and the conventional Rietveld factors $\left(R_{p}\right.$, $R_{\mathrm{wp}}$, and GOF) converged to satisfactory values. Solid solubilities of $\mathrm{Zn}, \mathrm{Mg}$, and $\mathrm{Cu}$ in $\alpha$-Al were extended to high values. Besides, metastable $\mathrm{Al}_{0.71} \mathrm{Zn}_{0.29}$, intermetallic $\mathrm{Al}_{2} \mathrm{CuMg}, \mathrm{Al}_{2} \mathrm{Cu}$, and $\mathrm{CuMgZn}$ phases have been observed for $x=4,8$, and $10 \mathrm{Cu}$ alloys. The crystal structure and microstructure characterizations exhibit strong $\mathrm{Cu}$ content dependence.
\end{abstract}

\section{Introduction}

The main attributes of rapid solidification are the extension of solid solution, refinement of structures in the nanometer range, production of fine dispersion of the second phase, synthesis of novel crystalline, and amorphous phases [1-4]. The Al-Zn alloys fulfill a significant fraction of industry's demand for the development of lightweight materials having high strength and toughness characteristics. $\mathrm{Cu}$ was added into the 7000 alloys to improve the stress corrosion cracking resistance [5, 6]. 7xxx series ( $\mathrm{Al}-\mathrm{Zn}-\mathrm{Mg}-\mathrm{Cu})$ aluminum alloys are widely used in the aircraft industry due to their low density and high strength [7]. It was reported that several intermetallic phases such as $\eta\left(\mathrm{MgZn}_{2}\right), T\left(\mathrm{Al}_{2} \mathrm{Mg}_{3} \mathrm{Zn}_{3}\right)$, $S\left(\mathrm{Al}_{2} \mathrm{CuMg}\right)$, and $\theta\left(\mathrm{Al}_{2} \mathrm{Cu}\right)$ can occur below the solidus [8-10]. The interaction in $\mathrm{Al}-\mathrm{Zn}$ alloys is rather weak and $\mathrm{Zn}$ atoms (atomic radius $1.39 \AA$ ) do not tend to form intermetallic phases with $\mathrm{Al}$ atoms (atomic radius $1.43 \AA$ ), which means that this size difference has a great influence upon the crystalline microstructure of Al-Zn alloys [11]. However, metastable $\mathrm{Al}_{0.71} \mathrm{Zn}_{0.29}$ phase has been observed by the author in melt spun Zn-22wt.\%Al-6wt.\%Ce [12]. This metastable phase disappeared by annealing $\left(300^{\circ} \mathrm{C} / 20 \mathrm{~h}\right)$ and has been also observed by others $[13,14]$. Rietveld method is becoming progressively more popular for microstructure characterization of materials. It is common practice to estimate domain size and strain values from the refined profile width parameters. Moreover, weight fractions of all phases in multiphase sample can be calculated directly by their scale factors which can be obtained by Rietveld fitting.

The relationship between relative weight fraction $\left(W_{i}\right)$ of each phase $i$ in a mixture of $n$ phases and its Rietveld scale factor $\left(S_{i}\right)$ can be obtained by the following relation [15]:

$$
W_{i}=\frac{S_{i}(Z M V)}{\sum_{i=1}^{n} S_{i}(Z M V)_{i}}
$$

where $Z, M$, and $V$ are number of formula units per cell, mass of the formula unite (in atomic mass units), and unit cell volume (in $\AA^{3}$ ), respectively. Moreover the March-Dollase function $P_{r}(\alpha)$ was applied to the observed hkl diffraction intensities during the refinements:

$$
P_{r}(\alpha)=\left(r^{2} \cos ^{2} \alpha+r^{-1} \sin ^{2} \alpha\right)^{-3 / 2},
$$

where $\alpha$ is the angle between the (HKL), which is the normal to a specific crystallographic plane, and (hkl) planes. The parameter $r$ is the compaction ratio of the original March model but in this paper we use $r$ to indicate the degree of preferred orientation; $r=1$ for random orientation and $r<1$ for sample containing preferred orientation. 
The object of this study is to investigate the influence of $\mathrm{Cu}$ content and rapid solidification on precipitation contents and microstructure characterizations of Al-8Zn- $4 \mathrm{Mg}-x \mathrm{Cu}, x$ $=1,4,8$, and 10 melt spun alloys, by using the Rietveld XRD analysis.

\section{Experimental Methods}

Al- $8 \mathrm{Zn}-4 \mathrm{Mg}-x \mathrm{Cu}, x=1,4,8$, and 10 alloys, were prepared from 99.99 wt.\% pure $\mathrm{Zn}, 99.75 \mathrm{wt}$ \% pure Al, 99.99 wt.\% pure $\mathrm{Cu}$, and $\mathrm{Al}-10$ wt.\% Mg master alloy. The melt spun alloys have been prepared as explained elsewhere [12]. The estimated cooling rate was about $10^{6} \mathrm{~K} / \mathrm{s}$. XRD patterns were performed using a 1390 Philips diffractometer, with filtered $\mathrm{Cu} \mathrm{K} \alpha 1$ radiation $(\lambda=0.154056 \AA)$ at $40 \mathrm{kV}$ and $20 \mathrm{~mA}$ in the $2 \theta$ range $20-90^{\circ}$.

In the present study, the Rietveld X-ray diffraction analysis [16-18] was carried out by the X'pert HighScore 2004 program and the Pseudo-Voigt peak shape function. The reliability of the refinement results was judged by the pattern $R$ factor $\left(R_{p}\right)$, the weighted pattern $R$ factor $\left(R_{\mathrm{wp}}\right)$, and the "goodness of fit"; GOF $=\left(R_{\mathrm{wp}} / R_{\text {expected }}\right)^{2}$ [19]. Initial structure parameters of all phases used for Rietveld method in this study were from ICCD (Inorganic Crystal Structure Database) cards. The parameters that had been refined simultaneously include scale factors, zero point shift, lattice parameters, atomic coordinates, atomic sites occupancies, isotropic or anisotropic temperature factors, profile shape parameter, FWHM (Full Width at Half Maximum) parameters, asymmetry, and preferred orientation parameters. The total parameters to be refined of $x=1,4,8$, and $10 \mathrm{Cu}$ melt spun alloys were $10,23,30$, and 31 .

\section{Results and Discussion}

Figure 1 shows the observed, calculated diffraction patterns and differences curves of $x=1,4,8$, and $10 \mathrm{Cu}$ melt spun alloys. The difference curves are flat and the values of $R$ factors are typical and satisfactory, which means that successful agreement is obtained between the observed and calculated diffraction patterns as shown in Table 1. Rietveld refinement results of $\alpha$-Al forthe melt spun alloys have been shown in Table 1 . The corresponding XRD lines of $\mathrm{Zn}(8 \%)$, $\mathrm{Mg}$ (4\%) were absent and the lattice constant of aluminum, $\mathrm{a}_{\alpha-\mathrm{Al}}$, increased from $4.0496 \AA$ to $4.0603 \AA$ (for $x=1 \mathrm{Cu}$ alloy) indicating the extent of the solid solubility of the alloying elements in $\alpha$-Al. By taking into account nominal atomic radii of $\mathrm{Al}(1.43 \AA), \mathrm{Cu}(1.278 \AA), \mathrm{Zn}(1.394 \AA)$, and $\mathrm{Mg}(1.602 \AA)$ [20], it is reasonable to assume that the $\alpha$-Al is a supersaturated solid solution of $\mathrm{Al}$ by $\mathrm{Zn}, \mathrm{Cu}$, and $\mathrm{Mg}$. This means that the cooling rate obtained in the melt spun technique was high enough to retain the alloying elements in a solid solution. Besides, average crystallites size and microstrain $\%$ of $\alpha$-Al phase were calculated from the refined profile width parameters and summarized in Table 1. The average crystallites size of $\alpha$-Al phase was in range of 22$38 \mathrm{~nm}$. By increasing $\mathrm{Cu}$ content, the average crystallites size of $\alpha$-Al decreased at the beginning and then increased

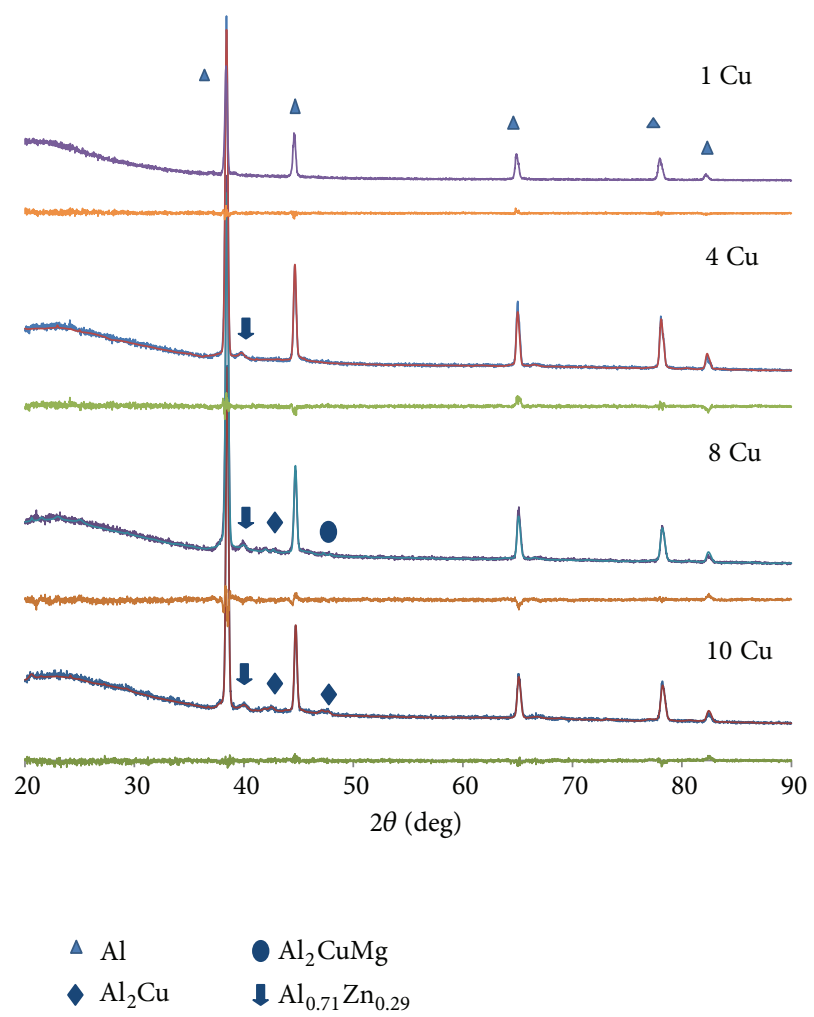

FIGURE 1: The observed profile (red points), calculated profile (solid line), and profile difference at the bottom of the Rietveld patterns for Al-8Zn- $4 \mathrm{Mg}-x \mathrm{Cu}, x=1,4,8$, and 10 melt spun alloys.

as shown in Figure 2(a). In addition, microstrain\% of $\alpha$ $\mathrm{Al}$ increased by constant rate and then decreased for $x=$ $10 \mathrm{Cu}$ melt spun alloy as shown in Figure 2(b) while the lattice constant of $\alpha$-Al decreased and then increased for $x=10 \mathrm{Cu}$ melt spun alloy as shown in Figure 2(c). A preferred orientation-correction refinement for $\alpha$-Al phase had a great influence on the matching between the calculated and observed XRD lines intensity and consequently on the Rietveld agreement factors for the melt spun alloys. The $\alpha$-Al phase exhibited preferred orientation in the crystallographic plane (111). XRD patterns of the intermetallic phases $\left(\mathrm{Al}_{0.71} \mathrm{Zn}_{0.29}, \mathrm{Al}_{2} \mathrm{CuMg}\right.$, and $\left.\mathrm{Al}_{2} \mathrm{Cu}\right)$ observed in the melt spun alloys have been separately expanded and well illustrated in $35-50^{\circ} 2 \theta$ range as shown in Figure 3 . The calculated weight percent (wt.\%), lattice constant $a_{\alpha \mathrm{Al}}$ (in $\AA$ ), volume of the unit cell (in $\AA^{3}$ ), and atomic coordinates of $\mathrm{Al}_{0.71} \mathrm{Zn}_{0.29}, \theta\left(\mathrm{Al}_{2} \mathrm{Cu}\right)$, and $S\left(\mathrm{Al}_{2} \mathrm{CuMg}\right)$ intermetallic phases obtained by Rietveld refinement are summarized in Table 2. Metastable $\mathrm{Al}_{0.71} \mathrm{Zn}_{0.29}$ intermetallic phase has been observed for $x=4,8$, and $10 \mathrm{Cu}$ alloys with wt.\% contents of $1.1,2$, and 1 , respectively. It is obvious that the unit cell of the melt spun $\mathrm{Al}_{0.71} \mathrm{Zn}_{0.29}$ phase has expanded, and therefore $\mathrm{Al}_{0.71} \mathrm{Zn}_{0.29}$ phase can be attributed as supersaturated solid solution. In addition, for $x=4 \mathrm{Cu}$ alloy, very weak peaks corresponding to intermetallic $\mathrm{Al}_{2} \mathrm{CuMg}$ phase (0.6 wt.\%) have been detected, and therefore the decreasing of $a_{\alpha-\mathrm{Al}}$ $(4.05462 \AA)$ by increasing of $\mathrm{Cu}$ content from $x=1$ to 


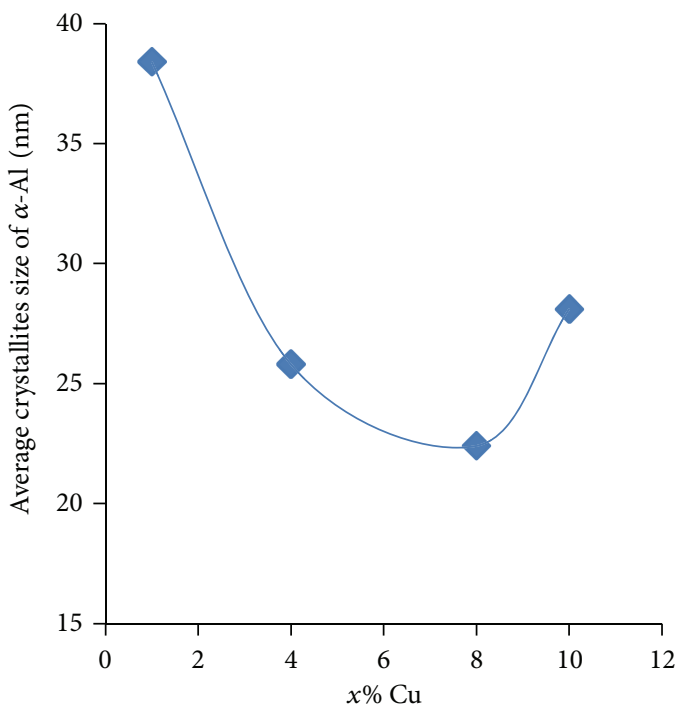

(a)

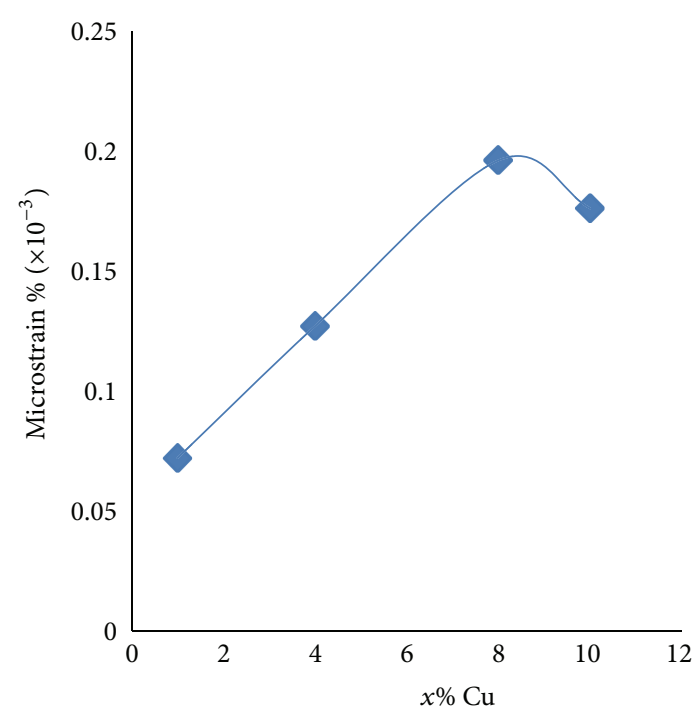

(b)

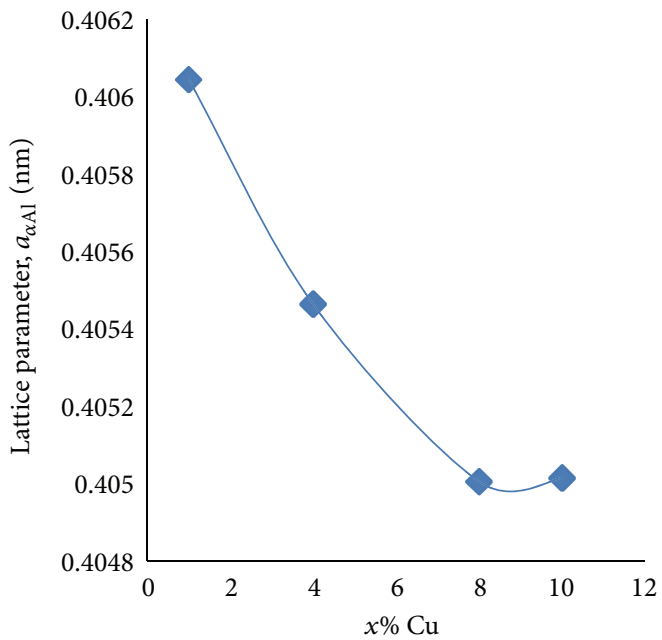

(c)

FIGURE 2: Calculated average crystallite size (a), microstrain\%, and lattice constant (c) of $\alpha$-Al as a function of Cu (wt.\%) content for $\mathrm{Al}-8 \mathrm{Zn}$ $4 \mathrm{Mg}-x \mathrm{Cu}, x=1,4,8$, and 10 melt spun alloys.

TABLE 1: Rietveld refinement results of Al-8\%Zn-4\%Mg- $x \% \mathrm{Cu}, x=1,4,8$, and 10 (in wt.\%) melt spun alloys.

\begin{tabular}{|c|c|c|c|c|c|c|c|c|}
\hline \multirow{2}{*}{ Sample } & \multirow{2}{*}{$\begin{array}{l}\text { Preferred ordination } \\
\text { parameter }\end{array}$} & \multirow{2}{*}{$\begin{array}{l}\text { Lattice constant }(\AA) \text { and volume } \\
(V) \text { of unit cell }\left(\AA^{3}\right) \text { for } \alpha \text {-Al }\end{array}$} & \multirow{2}{*}{$\begin{array}{l}\text { Average crystallite } \\
\text { size }(\mathrm{nm})\end{array}$} & \multirow{2}{*}{$\varepsilon \%$} & \multicolumn{4}{|c|}{ Agreement factors } \\
\hline & & & & & $R_{\mathrm{p}}$ & $R_{\mathrm{wp}}$ & $R_{\exp }$ & GOF \\
\hline $1 \% \mathrm{Cu}$ & 0.98 & $\begin{array}{c}4.06043 \\
V=66.94\end{array}$ & 38 & 0.072 & 7.49 & 10.67 & 9.10 & 1.37 \\
\hline $4 \% \mathrm{Cu}$ & 0.87 & $\begin{array}{c}4.05462 \\
V=66.66\end{array}$ & 26 & 0.127 & 5.78 & 7.78 & 6.39 & 1.48 \\
\hline $8 \% \mathrm{Cu}$ & 0.82 & $\begin{array}{c}4.05004 \\
V=66.43\end{array}$ & 22 & 0.196 & 5.67 & 7.60 & 5.84 & 1.69 \\
\hline $10 \% \mathrm{Cu}$ & 0.85 & $\begin{array}{c}4.05013 \\
V=66.44\end{array}$ & 30 & 0.163 & 4.74 & 6.52 & 5.82 & 1.25 \\
\hline
\end{tabular}




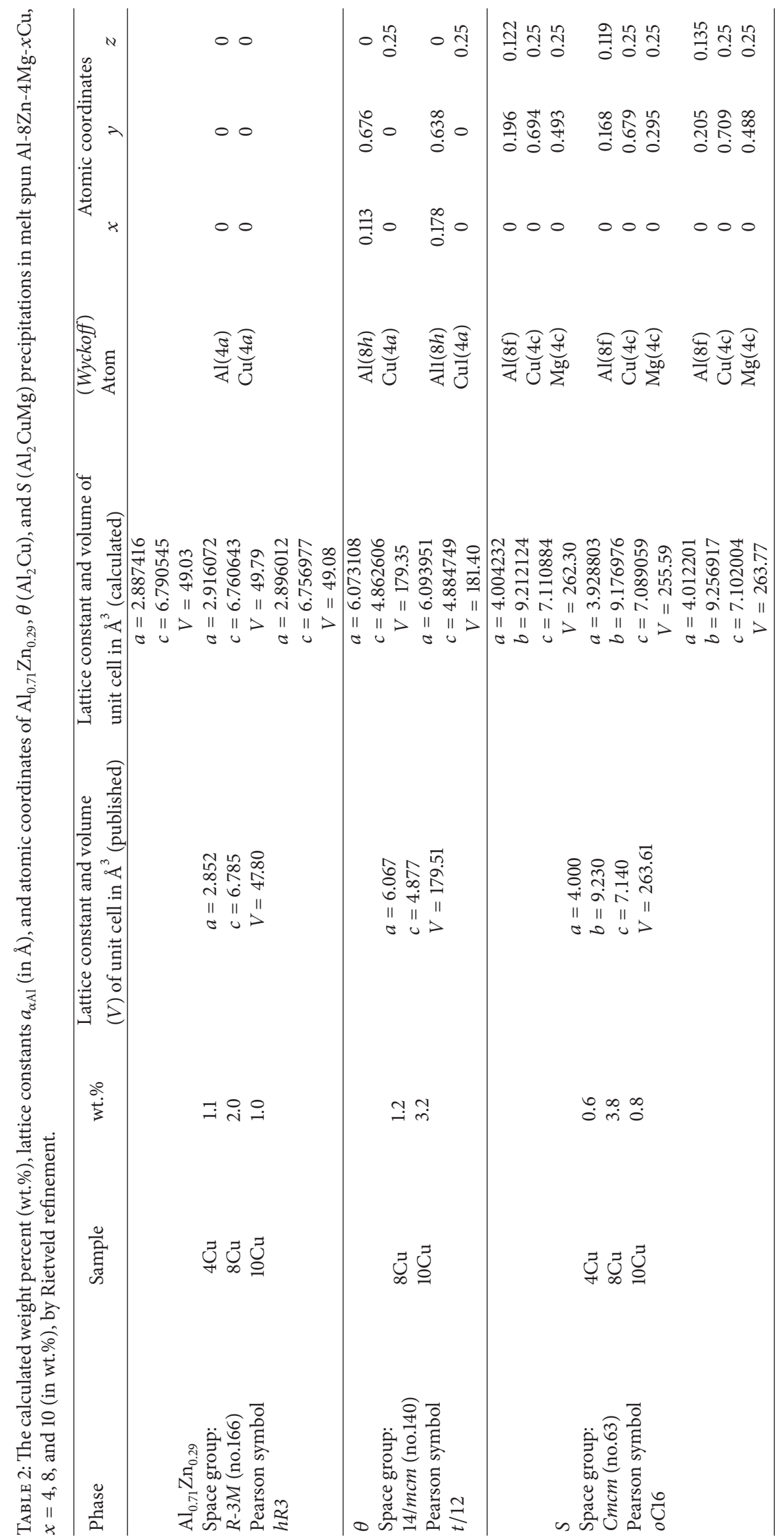



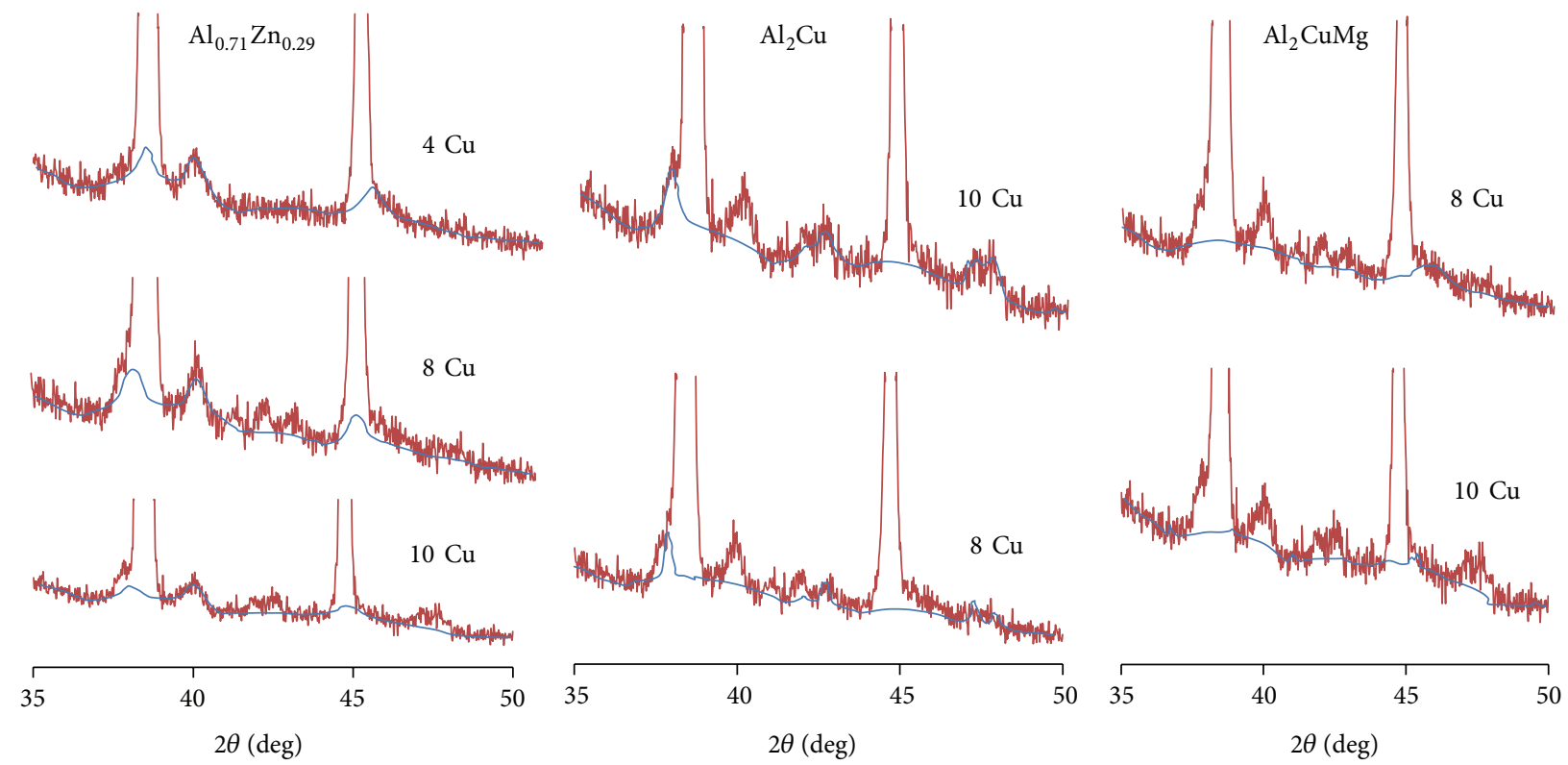

Figure 3: Calculated profiles (blue solid line) for the metastable $\mathrm{Al}_{0.71} \mathrm{Zn}_{0.29}$, intermetallic $\mathrm{Al}_{2} \mathrm{Cu}$, and $\mathrm{Al}_{2} \mathrm{CuMg}$ phases and the observed profile (red solid line) in 35-50 $2 \theta$ range.

4\% may indicate that part of $\mathrm{Cu}$ content dissolves in $\alpha$ $\mathrm{Al}$. Moreover, $\mathrm{Cu}$ content seems to support the formation of the metastable $\mathrm{Al}_{0.71} \mathrm{Zn}_{0.29}$ phase except in $x=1 \mathrm{Cu}$ alloy. Similarly, $6 \%$ Ce supported the formation of metastable $\mathrm{Al}_{0.71} \mathrm{Zn}_{0.29}$ phase in $\mathrm{Zn}-22 \mathrm{Al}-6 \mathrm{Ce}$ (in wt.\%) melt spun alloy prepared and discussed by the author [12]. Further decrease of $a_{\alpha \text {-Al }}(4.05004 \AA)$ has been observed by increasing of $\mathrm{Cu}$ content to $8 \%$, which can be attributed to the increasing of the solute $\mathrm{Cu}$ atoms in $\alpha$-Al, while $a_{\alpha \text {-Al }}$ increased a little bit $(4.050138 \AA)$ for $x=10 \mathrm{Cu}$ alloy which may indicate that the saturation solubility of $\mathrm{Cu}$ in $\alpha$-Al has reached (maximum solubility of $\mathrm{Cu}$ in $\alpha$ - $\mathrm{Al}$ is $5.4 \%$ at $548^{\circ} \mathrm{C}$ ) and a few of $\mathrm{Mg}$ atoms (1.602 $\AA$ ) have been dissolved in $\alpha$-Al. The calculated lattice parameters and atomic coordinates for the trigonal metastable $\mathrm{Al}_{0.71} \mathrm{Zn}_{0.29}$, tetragonal intermetallic $\mathrm{Al}_{2} \mathrm{Cu}$, and orthorhombic intermetallic $\mathrm{Al}_{2} \mathrm{CuMg}$ phases agree very well with published data with some refinements for the refinable coordinates as shown in Table 2. In general, the unit cell of each intermetallic phase in melt spun alloys exhibited contraction or expansion as the composition varies across it. For low $\mathrm{Cu}$ content where $\mathrm{Cu} / \mathrm{Mg}$ ratio is close to one $(x=4$ $\mathrm{Cu}$ alloy), little amount of $\mathrm{Al}_{2} \mathrm{CuMg}(0.6 \mathrm{wt} . \%)$ was formed. Increasing of $\mathrm{Cu}$ content where $\mathrm{Cu} / \mathrm{Mg}=2(x=8 \mathrm{Cu}$ alloy $)$ leads to formation of little amount of $\mathrm{Al}_{2} \mathrm{Cu}$ phase (1.2 wt.\%) and $\mathrm{Al}_{2} \mathrm{CuMg}$ phase became dominant (3.8 wt.\%). Further increasing of $\mathrm{Cu}$ content where $\mathrm{Cu} / \mathrm{Mg}>2(x=10 \mathrm{Cu}$ alloy), $\mathrm{Al}_{2} \mathrm{Cu}$ became dominant (3.2 wt.\%) with little amount of $\mathrm{Al}_{2} \mathrm{CuMg}(0.8 \mathrm{wt} . \%)$ as shown in Figure 3. This means that the formation of $\mathrm{Al}_{2} \mathrm{CuMg}$ intermetallic phase is preferable only at lower $\mathrm{Cu}$ contents. This replacement between the two intermetallic phases by increasing of $\mathrm{Cu}$ content was also observed in the casting AlCuMg alloys [21]. Besides, the intermetallic CuMgZn phase has been observed for $x=8$ and $10 \mathrm{Cu}$ alloys with lower contents $(0.1 \%$ and $0.3 \%)$.

\section{Conclusion}

The Rietveld X-ray diffraction analysis was successfully applied for analyzing the crystal structure and precipitation contents of the Al-8Zn-4Mg- $x \mathrm{Cu}, x=1,4,8$, and 10 melt spun alloys. The "goodnesses of fit" were 1.37, 1.48, 1.69, and 1.25 for $x=1,4,8$, and $10 \mathrm{Cu}$ alloys, respectively. The cooling rate was high enough to mostly retain the alloying elements (8\% $\mathrm{Zn}, 4 \% \mathrm{Mg}$, and $1 \% \mathrm{Cu}$ ) as a solid solution in $\alpha-\mathrm{Al}$. Besides, the average crystallites size of $\alpha$-Al phase was in range of $22-38 \mathrm{~nm}$. The melt spun $\alpha$-Al phase exhibited preferred orientation in the plane (111). Metastable $\mathrm{Al}_{0.71} \mathrm{Zn}_{0.29}$ intermetallic phase was observed for all compositions except at low $\mathrm{Cu}$ content $(1 \% \mathrm{Cu})$ which means that $\mathrm{Cu}$ content may play a certain role in the formation of this metastable phase. It is found that the intermetallic $\mathrm{Al}_{2} \mathrm{CuMg}$ phase was preferably formed at lower $\mathrm{Cu}$ contents $(4$ and $8 \% \mathrm{Cu})$ rather than the intermetallic $\mathrm{Al}_{2} \mathrm{Cu}$ phase which was formed at higher $\mathrm{Cu}$ content $(10 \% \mathrm{Cu})$. As results of the rapid solidification obtained in the melt spun technique, the unit cell of all precipitation phases formed in melt spun alloys exhibited contraction or expansion depending on the kind of dissolved atoms.

\section{Conflict of Interests}

The author declared that he has no conflict of interests.

\section{Acknowledgment}

The author would like to acknowledge the National Research Center of Egypt for providing financial support for this research. 


\section{References}

[1] Z. B. Sun, J. Guo, X. P. Song, Y. 1. Zhu, and Y. Li, "Effects of Zr addition on the liquid phase separation and the microstructures of $\mathrm{Cu}-\mathrm{Cr}$ ribbons with 18-22 at.\% Cr," Journal of Alloys and Compounds, vol. 455, no. 1-2, pp. 243-248, 2008.

[2] L. J. Huang, G. Y. Liang, Z. B. Sun, and Y. F. Zhou, "Nanocrystallization and hydriding properties of amorphous melt-spun $\mathrm{Mg}_{65} \mathrm{Cu}_{25} \mathrm{Nd}_{10}$ alloy," Journal of Alloys and Compounds, vol. 432, no. 1-2, pp. 172-176, 2007.

[3] S. Yang, X. P. Song, X. S. Liu et al., "Magnetic properties enhancement of $\mathrm{Nd}_{2} \quad \mathrm{Fe}_{14} \mathrm{~B} / \alpha-\mathrm{Fe}$ nanocomposites with a combined addition of $\mathrm{Cu}$ and Ti," Journal of Applied Physics, vol. 93, no. 2, pp. 1199-1202, 2003.

[4] Y. Totik and M. Gavgali, "The effect of homogenization treatment on the hot workability between the surface and the center of AA 2014 ingots," Materials Characterization, vol. 49, no. 3, pp. 261-268, 2002.

[5] B. Sarkar, M. Marek, and E. A. Starke, "The effect of copper content and heat treatment on the stress corrosion characteristics of Ai6Zn-2Mg-X Cu alloys,' Metallurgical Transactions A, vol. 12, no. 11, pp. 1939-1943, 1981.

[6] A. Deschamps, Y. Drechet, and F. Livet, "Influence of copper addition on precipitation kinetics and hardening in $\mathrm{Al}-\mathrm{Zn}-\mathrm{Mg}$ alloy," Materials Science and Technology, vol. 15, no. 9, pp. 9931000, 1999.

[7] S. C. Wang, M. J. Starink, and N. Gao, "Precipitation hardening in Al- $\mathrm{Cu}-\mathrm{Mg}$ alloys revisited," Scripta Materialia, vol. 54, no. 2 , pp. 287-291, 2006.

[8] F. Y. Xie, X. Y. Yan, L. Ding et al., "A study of microstructure and microsegregation of aluminum 7050 alloy," Materials Science and Engineering A, vol. 335, no. 1-2, pp. 144-153, 2003.

[9] L. L. Rokhlin, T. V. Dobatkin, N. R. Bochvar, and E. V. Lysov, "Investigation of phase equilibria in alloys of the $\mathrm{Al}-\mathrm{Zn}-\mathrm{Mg}-$ $\mathrm{Cu}-\mathrm{Zr}-\mathrm{Sc}$ system," Journal of Alloys and Compounds, vol. 367, no. 1-2, pp. 10-16, 2004.

[10] X. M. Li and M. J. Starink, "Effect of compositional variations on characteristics of coarse intermetallic particles in overaged 7000 aluminium alloys," Materials Science and Technology, vol. 17, no. 11, pp. 1324-1328, 2001.

[11] H. Bedboudi, A. Bourbia, M. Draissiaa, S. Boulkhessaim, and M. Y. Debili, "Analysis of the solid solution microstructure of (HF) Al-Zn alloys," Defect and Diffusion Forum, vol. 303-304, pp. 39-53, 2010.

[12] E. Ahmed, "Physical properties of Zn- 22 wt.\% Al- $x$ wt.\% Ce melt spun eutectoid alloy," Crystal Research \& Technology, vol. 47, no. 6, pp. 689-695, 2012.

[13] M. S. Mohammadi, A. Simchi, and C. Gierl, "Phase formation and microstructural evolution during sintering of $\mathrm{Al}-\mathrm{Zn}-\mathrm{Mg}-$ Cu alloys," Powder Metallurgy, vol. 53, no. 1, pp. 62-70, 2010.

[14] W. Gao, D. Gifford, and Z.-Y. Liu, "Corrosion behaviour of zincalume and galvanised coatings in a sulphur-containing atmosphere," Transactions of the Institution of Professional Engineers New Zealand, vol. 24, no. 1, 1997.

[15] R. J. Hill and C. L. Howard, "Quantitative phase analysis from neutron powder diffraction data using the rietveld method," Journal of Applied Crystallography, vol. 20, pp. 467-474, 1987.

[16] H. M. Rietveld, "Line profiles of neutron powder-diffraction peaks for structure refinement," Acta Crystallographica, vol. 22, pp. 151-152, 1967.
[17] H. M. Rietveld, "A profile refinement method for nuclear and magnetic structures," Journal of Applied Crystallography, vol. 2, pp. 65-71, 1969.

[18] R. A. Young and D. B. Wiles, "Profile shape functions in rietveld refinements," Journal of Applied Crystallography, vol. 15, pp. 430-438, 1982.

[19] R. A. Young, The Rietveld Method, edited by R. A. Young, Oxford University Press/IUCr, 1996.

[20] M. Bauccio, ASM Metals Reference Book, ASM International, 6th edition, 2001.

[21] B. Zlaticanin, B. Radonjic, and Z. Marinkovic, "DSC investigation of high-copper AlCuMg alloys," in Materials and Technology, vol. 37, 2003. 

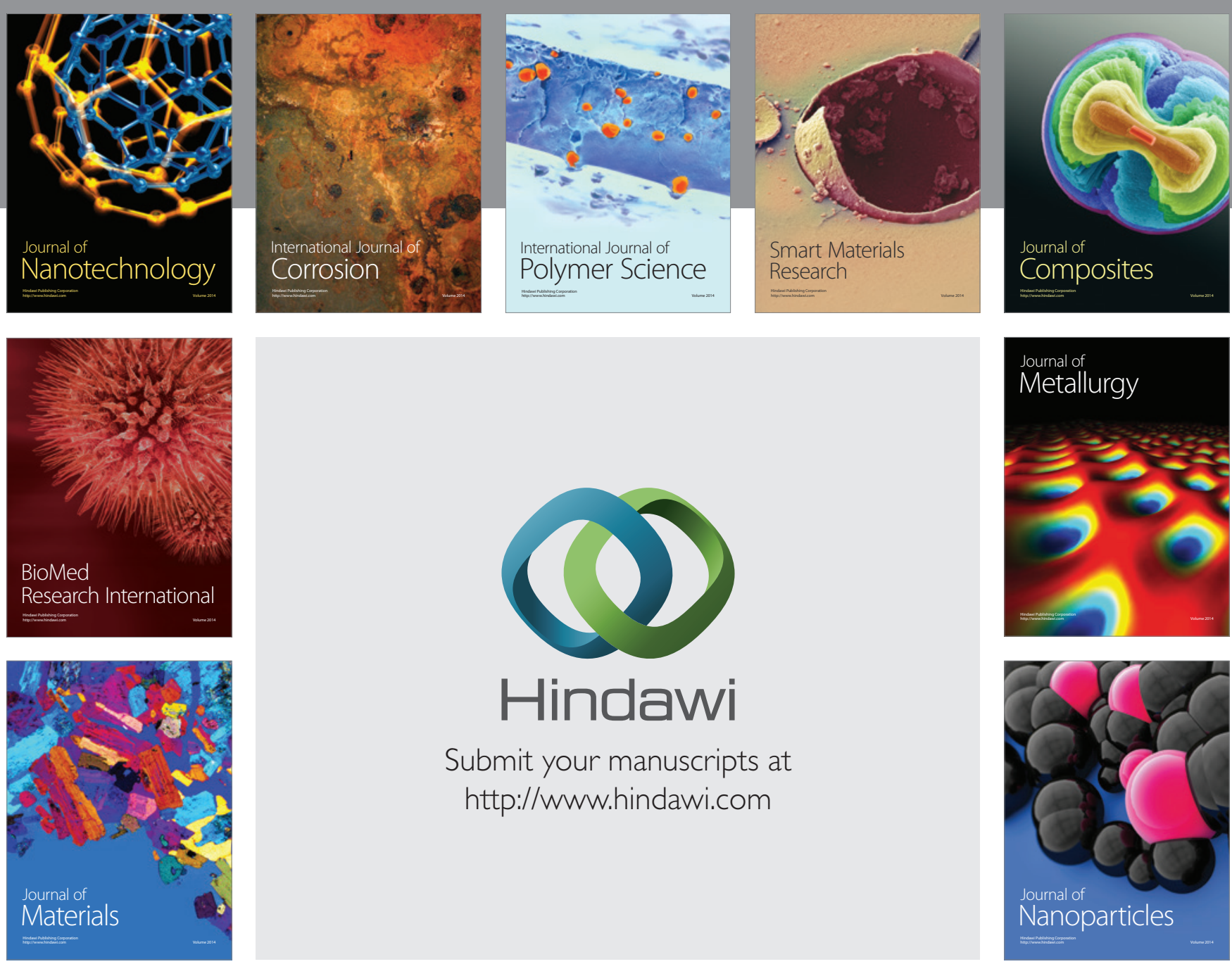

Submit your manuscripts at http://www.hindawi.com
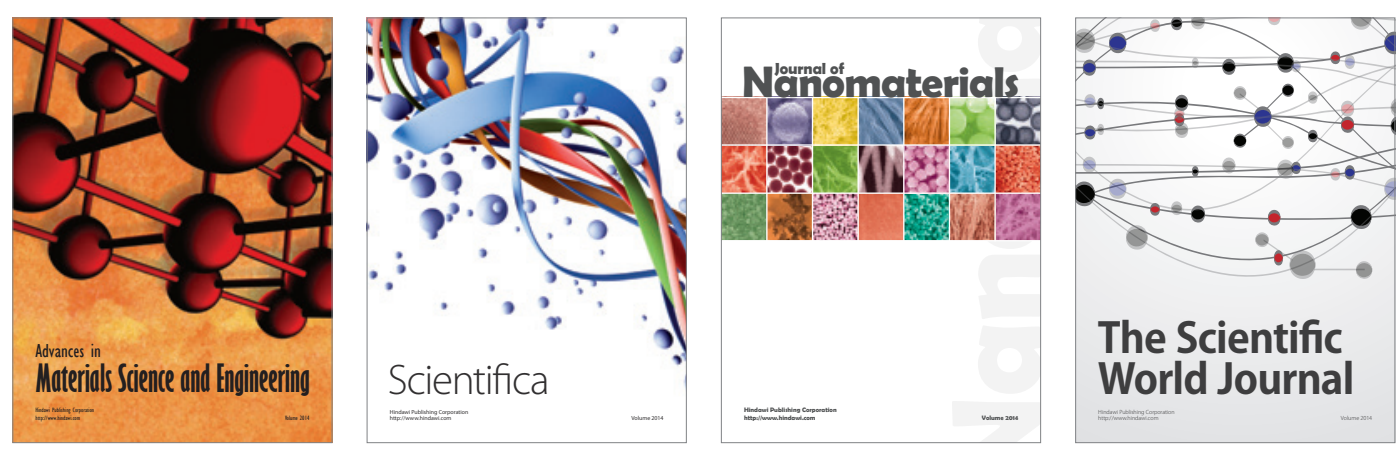

\section{The Scientific World Journal}
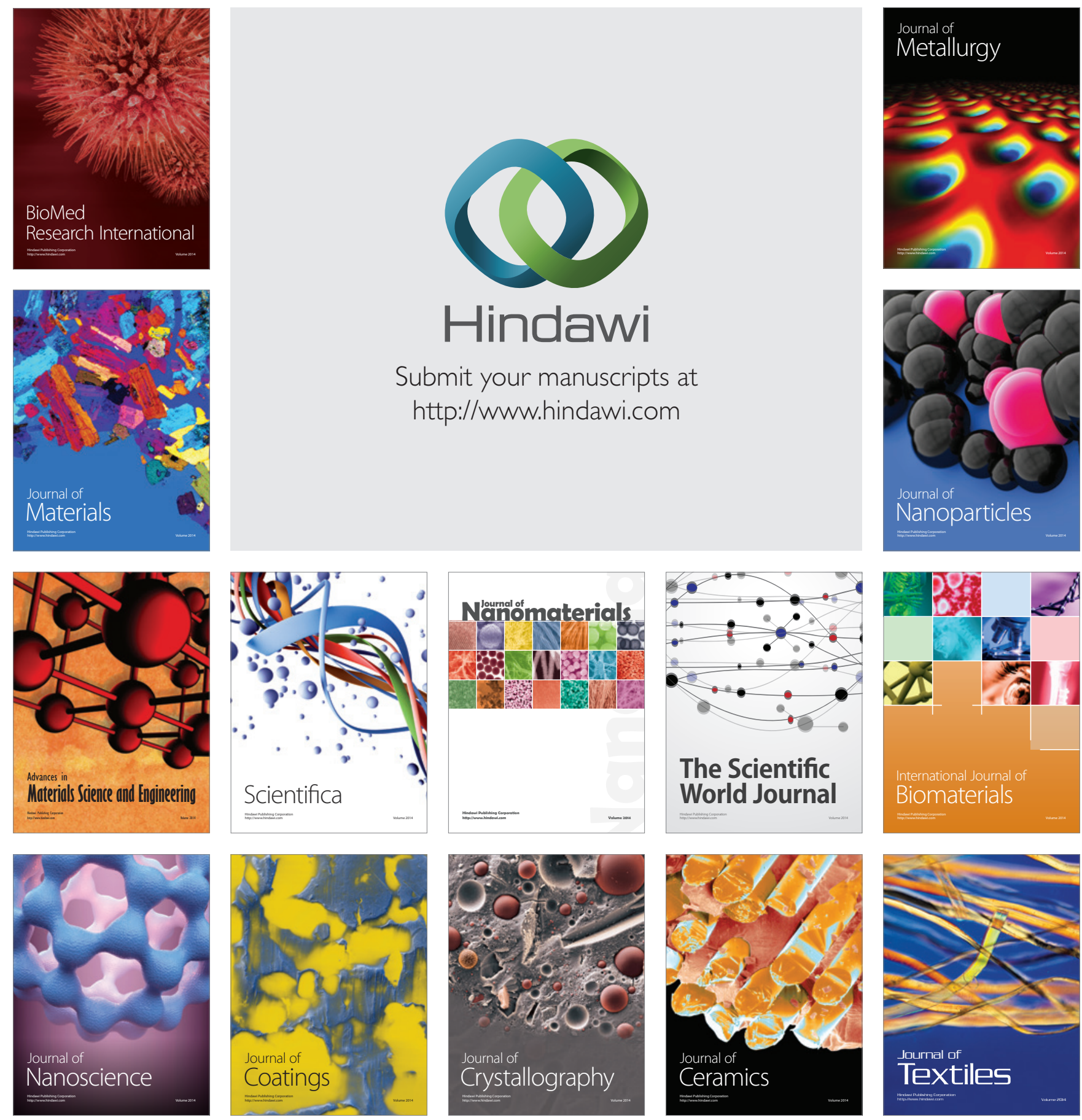